J. Perinat. Med. 15 (1987) 453

\section{Alternatives to the antenatal glucocorticoid treatment for the preven- tion of respiratory distress syndrome}

\author{
Joachim W. Dudenhausen \\ Institute for Perinatal Medicine - The Free University Berlin and Department of \\ Obstetrics, Womens Hospital Berlin-Neukölln, West Germany
}

\section{Introduction}

From the knowledge gained from various prospective studies, the incidence of respiratory distress (RDS) can be reduced by giving the mother glucocorticoids. Today due to fear of the side effects of such therapy, there has been a reduction in the use of prophylaxis with corticoids. Different substances and methods have been proposed for induction of antenatal lung maturation including thyroid hormones, Intralipid ${ }^{\circledR}$, ambroxol, carnitine, theophylline (aminophylline) and betamimetic agents.

\section{Thyroid hormones}

For a long time it has been known that there is a connection between lung maturity and thyroid gland metabolism [12]. Some authors found decreased $T_{3}$ and $T_{4}$ values in umbilical cord blood samples from infants who later developed RDS [1]. In 1974 in a study with MEINHOLD, we found a correlation between amniotic fluid lecithin and the reverse $\mathrm{T}_{3}$ level [11].

Studies performed on rats, rabbits and lambs have shown that thyroxine stimulates the phospholipid production in the fetal lung, where $T_{3}$ and $T_{4}$ receptors can be found. Since the transfer of $T_{3}$ and $T_{4}$ through the placenta is very minimal, the thyroxine has to be given intra-amniotically or into the fetus.

In human beings intra-amniotic instillation of thyroxine should increase lung maturity and lower the number of cases of RDS [10]. In order to measure the effectiveness of surfactant stimulation with thyroxine, 22 pregnant patients with a gesta- tional age of under 35 weeks were studied. The concentration of thyroxine and lecithin in amniotic fluid and in maternal and fetal serum were determined after giving an intra-amniotic dosage of $500 \mu \mathrm{g}$ levothyroxine [2]. The hormone determinations were performed radioimmunologically and the lecithin was determined enzymatically.

Groups were drawn up according to the interval between the instillation of $\mathrm{T}_{4}$ in the amniotic fluid and fresh normal amniotic fluid collected when the membranes ruptured at the start of labor. In this way a limit of 5 days was empirically created in 12 cases the interval was the same or less than 5 days (Group A), in the remaining 10 cases the time interval was more than 5 days (Group B).

Amniotic fluid: The mean value of the $\mathrm{T}_{4}$ concentration rises in Group A 18 times as the control group. In Group B the concentration is not different from the original level (figure 1). The mean value of $\mathrm{rT}_{3}$ after $\mathrm{T}_{4}$ injections into the amniotic fluid points to a significant increase which is about 13 times normal. In Group B no difference can be seen.

Umbilical cord blood: While the $\mathrm{T}_{4}$ and $\mathrm{rT}_{3}$ concentrations in Group A and B are significantly different, the $T_{3}$ concentrations are similar in both groups (figure 2). Similar results to the increase in $\mathrm{T}_{4}$ in umbilical cord blood were reported by RIDDICK et al in 1979 [14].

Maternal serum: The concentrations of $T_{4}, T_{3}$ and $\mathrm{rT}_{3}$ were measured before, 30 minutes after and 24 hours after $\mathrm{T}_{4}$ injections into the amniotic fluid (figure 3). No significant changes were to be seen in maternal blood. 


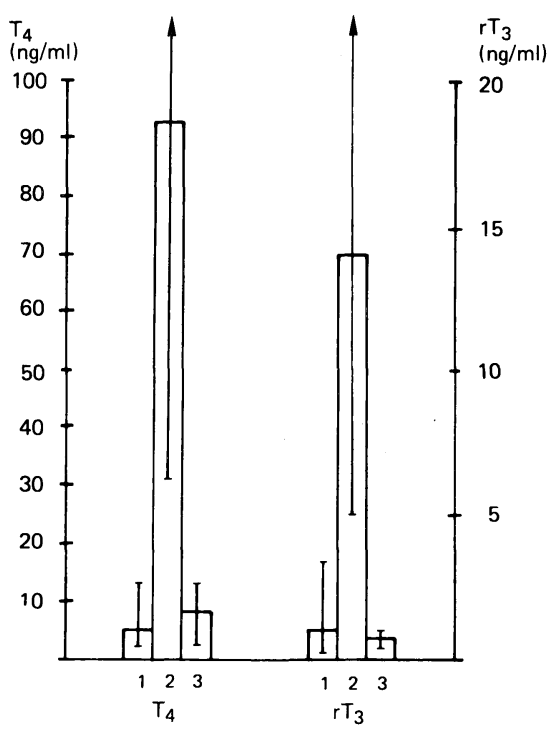

Figure 1. Median, maximum and minimum levels of $\mathrm{T}_{4}$ and $\mathrm{rT}_{3}$ in amniotic fluid before thyroxine dosage (1) and the start of labor, either in a time interval of exactly or less than 5 days between dosage and labor (2, Group A) or longer than 5 days (3, Group B).

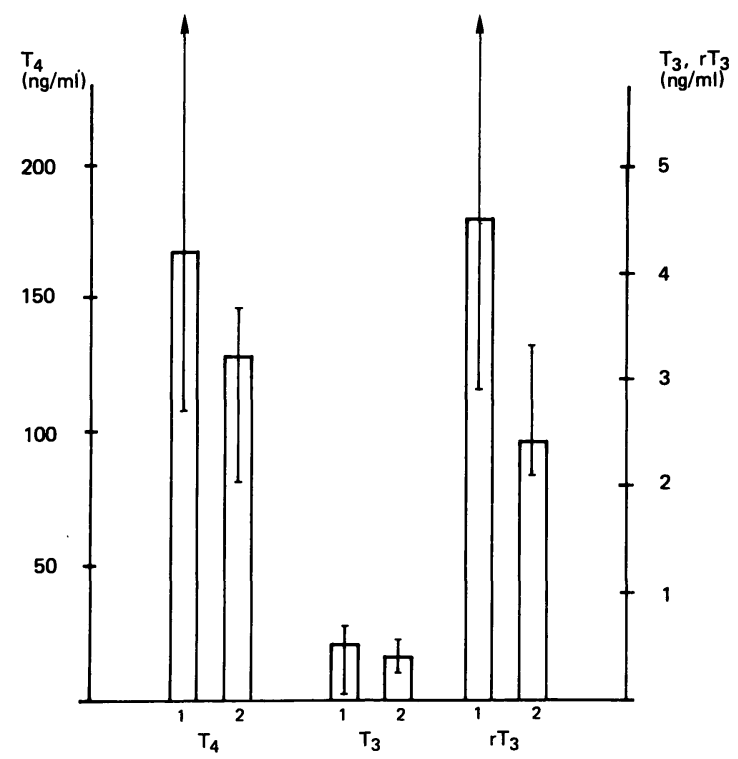

Figure 2. Median, maximum and minimum levels of $\mathrm{T}_{4}$, $\mathrm{T}_{3}$ and $\mathrm{rT}_{3}$ in umbilical cord vein blood in Group $\mathrm{A}$ (time interval between $\mathrm{T}_{4}$-Dosage and labor equal to or less than 5 days, 1) or Group B (time interval more than 5 days, 2 ).

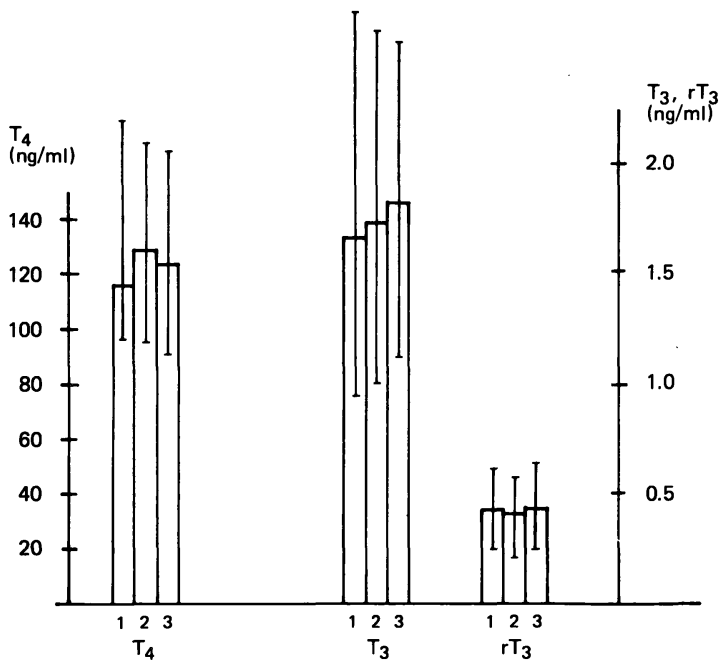

Figure 3. Median, maximum and minimum levels of $\mathrm{T}_{4}$, $\mathrm{T}_{3}$ and $\mathrm{rT}_{3}$ before thyroxine dosage (1), 30 minutes later (2) and 24 hours (3) after thyroxine dosage in maternal serum.

The results must be interpreted such that the $T_{4}$ injection into the amniotic fluid leads to an increase of $\mathrm{T}_{4}$ in the fetal blood. This clearly demonstrates that the $T_{4}$ injected into the amniotic fluid is absorbed by the fetus. However in the group where the interval between injection and delivery was more than 5 days, we observed that the $\mathrm{T}_{4}$ level had become normal again.

Thyroid hormones absorbed by the fetus will exercise their effect on various fetal organs. As an expression of the cardial effect of the thyroid hormones after thyroxine injection we found a moderate fetal tachycardia in 5 cases two days after the injection.

It seems that there is no paraplacental passage of the $\mathrm{T}_{4}$ injected into the maternal blood.

In addition to the hormone examination we also tested the lecithin concentrations in amniotic fluid before and after $\mathrm{T}_{4}$ injections; we observed a significant increase of the median values from 3.5 $\mathrm{mg} / 100 \mathrm{ml}$ to $5.2 \mathrm{mg} / 100 \mathrm{ml}$ after injection. The mean value in Group A was $5.6 \mathrm{mg} / 100 \mathrm{ml}$ and in Group B $4.3 \mathrm{mg} / 100 \mathrm{ml}$. The induction of surfactant production by means of thyroxine probably creates a reversible effect mechanism.

In this connection RDS diagnosed by neonatologists is important: While in our group about 8 
cases of RDS were to be expected, this diagnosis had only been made in 2 cases.

Therapy with thyroid hormone is possibly mediated through TRH, which can be administered to the patient intravenously and affects the infant through the placenta [13]. This type of lung maturation induction is still only in the testing stage at the moment.

There are suggestions that combined therapy with thyroid hormones and glucocorticoids has a marked effect on fetal lung maturity; however definite guidelines have not been drawn up [16].

Too little is known at present about the side effects of treatment with thyroid hormones or their analogous. Changes in growth or cerebral dysfunctions due to hyperthyroidism are possible. The risks involved in giving thyroxine with regard to increase in oxygen output are not understood although this increase does not necessarily have to be the same in all organs. The question of increased oxygen output of $\mathrm{T}_{4}$ injection would be of particular importance when dealing with fetuses with respiratory placental insufficiency.

\section{Intra-amniotic application of Intralipid ${ }^{\circledR}$}

OBERHEUSER and KLINK examined the possibility of stimulating surfactant formation by supplying a substrate of lecithin [6]. As the lecithins are supposedly not absorbed by the placenta, they have to be given intra-amniotically. They are able to prove in tests on rabbits, dwarf pigs and also on human subjects, that the lecithin is swallowed by the fetus and is absorbed in the intestine. The metabolism takes place in the liver. After resynthesis part of the lecithin is to be found in the pulmonary alveoli.

In the meantime the group has been able to prove the Intralipid ${ }^{\circledR}$ effects in tissue cultures of the human fetal lung, too.

On the basis of the mentioned observations they carried out intra-amniotic injection of Intralipid ${ }^{\circledR}$ in patients with premature labor between the 26 th -36 th week of gestation. They applied 60 $\mathrm{ml}$ Intralipid ${ }^{\circledR}$ in exchange for aspirated amniotic fluid which was used to determine the $\mathrm{L} / \mathrm{S}$ ratio. In all cases there was no evidence of premature rupture of membranes.

The frequency and degree of RDS in premature babies with a birth weight under $2500 \mathrm{~g}$ during the past 7 years in the University Hospital of Lübeck were evaluated in order to assess the efficacy of Intralipid ${ }^{\circledR}$ therapy.

Table I shows the frequency and degree of RDS in premature infants after Intralipid ${ }^{\circledR}$ application, corticosteroid therapy in the form of $2 \times 50 \mathrm{mg}$ Solu-Decortin ${ }^{\circledR}$ I. V. within the first 24 hours and cases without previous induction of fetal lung maturity.

Statistical significance of the efficacy of Intralipid ${ }^{\circledR}$ injection cannot be determined due to the small number of cases and the large difference in the individual groups. It should be pointed out, that no death was observed, and only one case with severe RDS was recorded. As far as mortality is concerned, corticosteroid therapy, as expected, is compared to untreated cases.

Table I. Frequency and degree of RDS after Intralipid ${ }^{\circledR}$ injection, after corticosteroid therapy and without lung maturation promotion [6].

\begin{tabular}{|c|c|c|c|c|}
\hline Birth weight & RDS & Intralipid $^{\circledR}$ & Corticoids & no treatment \\
\hline \multirow[t]{5}{*}{$800-1499 \mathrm{~g}$} & & $\mathrm{n}=4$ & $\mathrm{n}=18$ & $\mathrm{n}=21$ \\
\hline & $\varnothing$ & 1 & 5 & 3 \\
\hline & I. - II. ${ }^{\circ}$ & 2 & 11 & 8 \\
\hline & III. - IV. ${ }^{\circ}$ & 1 & 2 & 10 \\
\hline & + & 0 & 3 & 12 \\
\hline \multirow[t]{5}{*}{$1500-2500 \mathrm{~g}$} & & $\mathrm{n}=14$ & $\mathrm{n}=52$ & $\mathrm{n}=156$ \\
\hline & $\varnothing$ & 8 & 40 & 123 \\
\hline & I. - II. ${ }^{\circ}$ & 6 & 10 & 26 \\
\hline & III. - IV..$^{\circ}$ & 0 & 2 & 7 \\
\hline & + & 0 & 1 & 7 \\
\hline
\end{tabular}




\section{Ambroxol}

Clinical studies and experiments on animals have been performed for years in order to prove the effect of ambroxol on lung maturation. The effect is supposed to be dependent upon stimulation of the secretory cells in the alveolar epithelium. This mechanical effect has not been definitely clarified. Earlier clinical studies - some involving a smaller dosage than today - did not provide positive results [9]. In 1982 WAUER and coworkers, in a larger double-blind study, showed that in patients with a gestational age of 33 to 36 weeks, who had been given $1000 \mathrm{~g}$ ambroxol intravenously over a period of 5 days, the incidence of RDS was lower [17]. They did not find an effect before the 32nd week of gestation.

A German-Austrian multicenter double-blind study of 190 children examined the effects of betamethasone and ambroxol for antenatal pulmonary maturity induction between the 28 th and 36 th week of gestation. They showed that the same results were achieved with ambroxol as with betamethasone [15]. Ambroxol would have an advantage due to few long-term side effects. The disadvantage of the therapy is that it requires five days. It is not always possible to treat a patient effectively with tocolytic drugs for 5 days or to postpone a premature delivery.

\section{Carnitine}

Carnitine is known to be an important factor for breaking down fatty acids in humans. With increased gestational age, a rise in the carnitine content was measured in the fetal lung of the rat. The carnitine dosage given to the pregnant rat caused a rise in the carnitine level in the fetal lung [7].

The suggestion that pulmonary maturity induction could be achieved with carnitine assumes that carnitine encourages surfactant formation by intramitochondrial transport and regulation of the beta-oxydation of long chain fatty acids. The synthesis of palmitic acids, their insertion into mitochondrial phospholipids and also the formation of lecithin via methylation could be stimulated by carnitine. In animal experiments, LOHNINGER and coworkers were able to show that the combination of carnitine and betamethasone due to their different mechanisms, leads to a larger increase of phosphatidylcholin in the lung of the fetal rat than single dosages of the two substances [8]. Comparable results were found in the carnitine/thyroxin group.

\section{Aminophylline}

Animal studies of the effect of aminophylline on pulmonary maturity induction have been hopeful. HAJIGEORGIOU and coworkers have reported in a prospective study of a lessened incidence of RDS after treating mothers with aminophylline [5]. The effect is neither absolute, nor have the side effects been studied intensively. It is assumed that aminophylline increases the tissue content of cyclic AMP (cAMP) by inhibition of cAMP-phosphodiesterase. An increase in phospholipid synthesis takes place through the increased concentration of cAMP in the alveolar cells.

\section{Betasympathomimetic agents}

Betasympathomimetic agents are used to inhibit uterine contractions. Retrospective studies have shown that when used for a short period they decrease the incidence of RDS [4]. Possibly these agents also produce changes in the cAMP content and increase adenylcyclase or increase the release of surfactant from the lamellar bodies. The importance of betasympathomimetics is dependent on the amount given and the duration of therapy and has not been clarified definitely [3].

\footnotetext{
Abstract

Various substances and methods are used as alternatives to corticoids for stimulating antenatal pulmonary maturation. This study discusses thyroid hormones, Intrali-
}

pid $^{\circledR}$, ambroxol, carnitine, theophylline (aminophylline) and betasympathomimetic agents.

Keywords: Ambroxol, aminophylline, betasympathomimetics, carnitine, Intralipid ${ }^{\circledR}$, lung maturation promotion, prevention, RDS, thyroid hormones. 


\section{Zusammenfassung}

Alternativen zur antenatalen Glukokortikoid-Behandlung zur Vermeidung des Membransyndroms

Neben der Lungenreifeförderung mit Kortikoiden werden verschiedene Substanzen zur antenatalen Lungenreifeförderung benutzt, z. B. die Schilddrüsenhormone, Intralipid ${ }^{\circledR}$, Ambroxol, Carnitin, Theophyllin (Aminophyllin) und Betasympathomimetika.

Schilddrüsenhormone: Verschiedene Autoren haben $\mathrm{Zu}$ sammenhänge zwischen der Lungenreife und dem Schilddrüsenstoffwechsel nachgewiesen. Tierexperimente haben gezeigt, daß Thyroxin die Phospholipidsynthese in der fetalen Lunge steigert. Beim Menschen vermehrt intraamnial appliziertes Thyroxin die Lungenreife und senkt die Rate des Membransyndromes. Um die Effektivität der Surfactant-Stimulation mit Thyroxin zu prüfen, haben wir bei 22 Schwangeren mit einem Schwangerschaftsalter unter 35 Wochen die Konzentration an Schilddrüsenhormonen im Fruchtwasser, im mütterlichen und fetalen Plasma nach intraamnialer Gabe von $500 \mu \mathrm{g}$ L-Thyroxin untersucht. Die Ergebnisse zeigen, daß das Thyroxin vom Feten resorbiert wird. In der Gruppe, in der zwischen Injektion und Geburt mehr als 5 Tage liegen, sahen wir eine Normalisierung des Thyroxin. Die Schilddrüsenhormone haben Effekte an verschiedenen fetalen Organen, so z. B. am Herzen, sichtbar an einer mittelgradigen Tachykardie in einigen Fällen zwei Tage nach der Injektion. Neben den Hormonbestimmungen haben wir vor und nach der Thyroxin-Injektion die Lezithin-Konzentration im Fruchtwasser gemessen; wir sahen einen signifikanten Anstieg. Allerdings scheint die Surfactant-Produktion durch Thyroxin ein reversibler Vorgang zu sein.
Intralipid ${ }^{\circledR}$ : Eine Autorengruppe prüfte die Stimulation der Surfactant-Bildung durch die intraamniale Gabe von Lezithinen. Sie wies tierexperimentell und auch am Menschen nach, daß das Lezithin vom Feten geschluckt und im Darm resorbiert wird. Nach Metabolisation in der Leber und Resynthese findet sich das Lezithin wieder in der Alveole. Auf diese Grundlage wurden Frauen mit vorzeitigen Wehen zwischen der 26. und 36 . Woche mit $60 \mathrm{ml}$ Intralipid ${ }^{\circledR}$ intraamnial behandelt. In der Gruppe fand sich kein Todesfall, nur ein Fall mit schwerem Membransyndrom.

Ambroxol: Der Effekt des Ambroxol auf die Lungenreife wird in der Stimulation der sekretorischen Pneumozyten des Alveolarepithels gesehen, allerdings ist dieser Vorgang nicht definitiv geklärt. 1982 wurde eine größere Doppelblindstudie publiziert, die eine Minderung der Membransyndrom-Rate bei Patientinnen zwischen der 32. und 36. Woche zeigte, denen $1000 \mathrm{~g}$ Ambroxol intravenös über fünf Tage gegeben worden war. Unter der 32. Woche fand sich keine Wirkung.

Carnitin: Mit ansteigendem Schwangerschaftsalter ist ein ansteigender Gehalt der fetalen Rattenlunge an Carnitin meßbar. Außerdem steigert die Carnitingabe an schwangere Ratten den Carnitin-Gehalt der fetalen Lunge.

Aminophyllin: In einer prospektiven Studie zeigte sich eine niedrigere Membransyndrom-Rate Aminophyllinbehandelter Mütter. Der Effekt ist noch nicht vollkommen gesichert, außerdem sind die Nebenwirkungen noch nicht intensiv untersucht.

Betasympathomimetika: Retrospektive Untersuchungen haben die Minderung der Membransyndrom-Rate nach Kurzzeitgabe von Betasympathomimetika belegt.

Schlüsselwörter: Ambroxol, Aminophyllin, Betasympathomimetika, Carnitin, Intralipid ${ }^{\circledR}$, Lungenreifeförderung, Prävention, RDS, Schilddrüsenhormone.

\section{Résumé}

\begin{abstract}
Alternatives au traitement glucocorticoïde antenatal pour la prévention du SDR chez le nouveau-né

Outre les corticoïdes, diverses substances et méthodes sont utilisées pour stimuler la maturation pulmonaire anténatale, à savoir les hormones thyroïdiennes, l'Intrali pid $^{\circledR}$, l'ambroxol, la carnitine, la théophylline (aminophylline) et les bétamimétiques.
\end{abstract}

Hormones thyrö̈diennes: On a su à partir de certains auteurs qu'il existait des relations entre la maturité pulmonaire et le métabolisme de la glande thyroïde. Des études ont été réalisées chez le rat, le lapin et l'agneau, études qui ont montré que la thyroxine stimule la production de phospholipides dans le poumon fotal. Dans l'espèce humaine des instillations intra-amniotiques de thyroxine augmenteraient la maturité pulmonaire et diminueraient le nombre de cas de syndrome de membranes hyalines. Afin de faire le bilan de l'efficacité de la stimulation du surfactant par la thyroxine chez 22 femmes enceintes avec un âge gestationnel inférieur à 35 semaines, nous avons étudié l'évolution de la concentration en hormone thyroïdienne dans le liquide amniotique, dans le sang maternel et fotal après administration intra-amniotique de $500 \mu \mathrm{g}$ de levothyroxine. Les résultats sont à interpréter car la T4 injectée dans le liquide amniotique est résorbée par le fœtus.

Toutefois, dans le groupe pour lequel l'intervalle entre l'injection et l'accouchement a été supérieur à 5 jours, nous avons observé que les taux de T4 s'étaient de nouveau normalisés. Les hormones thyroïdiennes résorbées par le fætus exercent leurs effects sur divers organes fotaux. Comme expression de l'effet cardiaque, des hormones thyroïdiennes après injection de thyroxine, nous avons trouvé une tachycardie fotal modérée, dans quelques cas, deux jours après l'injection. En complément du bilan hormonal, nous avons également dosés les concentrations de lécithine dans le liquide amniotique avant et après injections de T4. Nous avons observé une augmentation significative des valeurs moyennes après 
injection. L'induction de la production de surfactant au moyen de la thyroxine crée probablement un mécanisme réversible.

Intralipid ${ }^{\circledR}$ : Dans la littérature, un groupe de recherche a examiné la possibilité de stimuler la formation de surfactant grâce à l'apport d'un substrat de lecithine. Comme les lécithines ne sont pas supposés être absorbés par le placenta, il faut les administrer en intra-amniotique. Les auteurs ont pu prouver par des tests chez l'animal et également chez des sujets humains que la lécithine est déglutie par le fotus et absorbée dans l'intestin. La métabolisation s'effectue dans le foie. Après resynthèse, une partie de la lecithine est retrouvée dans les alvéoles pulmonaires. Sur la base des observations mentionnées, ils ont réalisé l'administration intra-amniotique de $60 \mathrm{ml}$ d'Intralipid ${ }^{\circledR}$ chez des patients avec un accouchement prématuré entre la 26è et la 36è semaine de gestation. Il faut insister sur le fait que le taux de mortalité a été nul et que seul un cas a présenté un SDR sévère.

Ambroxol: L'effet de l'ambroxol sur la maturation pulmonaire est supposé dépendre d'une stimulation des cellules sécrétoires de l'épithélium alvéolaire. Toutefois, cet effet mécanique n'a pas été définitivement clarifié. En 1982 une étude en double aveugle plus importante a été publié; elle montre que chez les patientes avec un âge gestationnel de 33 à 36 semaines, auxquelles on a injecté $1000 \mathrm{~g}$ d'ambroxol par voie intra-veineuse sur une période de 5 jours, l'incidence du syndrome des membranes hyalines est plus faible. Néanmoins, on n'a pas trouvé d'effet avant la 32è semaine de gestation.

Carnitine: Avec l'élévation de l'âge gestationel, on a mesuré une élévation de la teneur en carnitine dans le poumon fotal chez le rat et l'apport de carnitine à la rate gravide entraine une élévation du taux de carnitine dasn le poumon fœtal.

Aminophylline: Il a été vu dans une étude prospective une minoration de l'incidence du syndrome de membranes hyalines après traitement maternel par aminophylline. L'effet n'est pas certain d'une part et d'autre part les effects secondaires n'ont pas été étudiés de façon intensive.

Bétamimétiques: Des études rétrospectives ont montré que lorsqu'on les utilise pendant une courte période, ils diminuent l'incidence du syndrome des membranes hyalines.

Mots-clés: Ambroxol, amélioration de la maturation pulmonaire, aminophylline, bétamimétiques, carnitine, Intralipid ${ }^{\circledR}$, prévention, SDR.

\section{References}

[1] Dhamireddy R, YF Smith, M Hamosh, DK MulLON, JW ScanlON, P HAMOSH: Respiratory distress syndrome in the newborn: Relationship to serum prolactin, thyroxine, and sex. Biol Neonate 43 (1983) 9

[2] Dudenhausen JW: Wirkungen der intraamnialen Thyroxingabe auf den Feten. Geburtshilfe Frauenheilkd 44 (1984) 777

[3] Dudenhausen JW, G Kynast, A-M Lange-LindBERG, E SALING: Influence of long-term betamimetic therapy on the lecithin content of amniotic fluid. Gynecol Obstet Invest 9 (1978) 205

[4] GERNER R: Untersuchungen zur Beeinflussung der Lezithinsynthese in der fetalen Lunge durch Tokolytika. In: SChmidt E, JW Dudenhausen, E SALING: Perinatale Medizin Band VII. 8. Deutscher Kongreß für Perinatale Medizin 1977. Thieme, Stuttgart 1978

[5] Hadjigeorgiou E, S Kitsiuo, A Psaroudakis, C Segos, D Nicolopoulos, D Kasakarelis: Antepartum aminophylline treatment for prevention of the respiratory distress syndrome in premature infants. Am J Obstet Gynecol 135 (1979) 257

[6] Klink F, L v Klitzing, D Kleinbauer, H KunKelMANN, F OBERHEUSER: Prenatale respiratory distress syndrodrome prophylaxis through intraamniotic application of Intralipid ${ }^{\circledR}$. 10th European Congress of Perinatal Medicine, Leipzig, August 12-16, 1986
[7] LOHNINGER A, HP Krieglsteiner, A Nikoforov, W ERHARDT, M SPECHER, G MARTIN, E KaISER: Comparison of the effects of betamethasone and L-carnitine on dipalmitoyl phosphatidylcholine content and phosphatidylcholine specien composition in fetal rat lungs. Pediatr Res 18 (1984) 1246

[8] Lohninger A, HP Krieglsteiner, H SAlzer, E VyTISKA-BINSTORFER, W RIEDL, W ERHARDT: Studies on the effects of betamethasone, L-carnitine and betamethasone-L-carnitine combinations on the dipalmitoyl-phosphaditylcholine content and phosphatidylcholine species composition in fœtal rat lungs. J Clin Chem Clin Biochem 24 (1986) 361

[9] LoRenz U, R RüTtgers, F KuBLI: Klinische Doppelblindstudie zur Frage der antepartalen Lungenreifung unter Ambroxol. Atemwegs- u. Lungenkrankheiten 4, Suppl 1 (1978) 30

[10] Mashiach S, G Barkai, J Sack, E Stern, M Brish, B GOLDMAN, DM SERR: The effect of intra-amniotic thyroxine administration on fetal lung maturity in man. J Perinat Med 7 (1979) 161

[11] Meinhold H, JW Dudenhausen, KW Wenzel, E SALING: Amniotic fluid concentrations of 3, 3', 5'triiodothyronine (reverse $\mathrm{T}_{3}$ ), 3, $3^{\prime}$-diiodothyronine, $3,5,3^{\prime}$-tri-iodothyronine $\left(\mathrm{T}_{3}\right)$ and thyroxine $\left(\mathrm{T}_{4}\right)$ in normal and complicated pregnancy. Clin Endocrinol 10 (1979) 355

[12] Morishige WK, DL Guernsey: Triiodothyronine receptors in rat lung. Endocrinology 102 (1978) 1628 
[13] Morley Je, RA Bashore, A Reed, he Carlson, JM HERSHMAN: Thyrotropin-releasing hormone and thyroid hormones in amniotic fluid. Am J Obstet Gynecol 134 (1979) 581

[14] RidDick DH, JA MASLAR, AA Luciano, JR RAYE: Thyroxine uptake and metabolism by fetal sheep after intra-amniotic thyroxine injection. Am J Obstet Gynecol 133 (1979) 618

[15] Salzer H, H Weidinger, G Simbruner, E VytisKaBiNSTORFER: Ambroxol versus Betamethason zur Förderung der antepartalen Lungenreife - eine multizentrische Studie. Z Geburtshilfe Perinatol 190 (1986) 49

[16] TORDAY JS, KE Dow: Synergistic effect of triiodothyronine and dexamethasone on male and female fetal rat lung surfactant synthesis. Dev Pharmacol Ther 7 (1984) 133
[17] Wauer RR, G Schmalisch, K Menzel, M SCHRÖDER, K MÜller, R TILlER, G MethFESSEL, U Sitka, E Koepke, CH Plath, C Schlegel, M BOTTCHER, I KÖPPE, U FrICKe, $K$ SEVERIN, R J $J_{A-}$ COBI, W SCHMIDT, GK HiNKel, I NiTZ, D KUNZE, G ReichmanN, B LachmanN, $\mathrm{K}$ Lampe, EL GRAUEL: The antenatal use of ambroxol (bromhexine metabolite VIII) to prevent hyaline membrane disease: A controlled double-blind study. Biol Res Pregnancy 3 (1982) 84

Prof. Dr. Joachim W. Dudenhausen Univ.-Frauenklinik

Frauenklinikstr. 10

CH-8091 Zürich, Switzerland 


\section{Receptor Medicted Antisteroid Action}

\section{Editor M. K. Agarwal}

$1987.17 \mathrm{~cm} \times 24 \mathrm{~cm}$. VIII, 524 pages. Numerous illustrations. Hardcover. DM 298,-; approx. US \$175.00 ISBN 3110113554

This volume groups together latest conceptual developments and ongoing designs for antagonists in all groups of steroid hormones at the pharmacological, biochemical, and clinical level. New biochemical and immunocytochemical approaches to probe the nature of receptor localization and function have been reviewed as well. The influence of antisteroids in modifying behaviour, steroid hormones in insects, and the approach of idiotype selection to study hormone action, have been included to give the volume even wider appeal.

All authors are active in the fields in which they have contributed and the collection of papers by experts under one single cover provides the opportunity to glance at material one would not otherwise read. It is certain that this multidisciplinary approach will lead to the cross fertilization of ideas so necessary for further conceptual and practical effort to dissect the receptor and use it to alleviate disease. 